\title{
Pricing Models for Cloud Computing Services, a Survey
}

\author{
Taj Eldin Suliman M. Ali \\ College of Graduate Studies, \\ Computer Science and Information Technology \\ Sudan University for science and technology \\ Khartoum, Sudan
}

\author{
Hany H. Ammar \\ Lane Department of Computer Science and \\ Electrical Engineering, \\ College of Engineering and Mineral Resources \\ West Virginia University \\ Morgantown, USA
}

\begin{abstract}
Recently, citizens and companies can access utility computing services by using Cloud Computing. These services such as infrastructures, platforms and applications could be accessed on-demand whenever it is needed. In Cloud Computing, different types of resources would be required to provide services, but the demands such as requests rates and user's requirements of these services and the cost of the required resources are continuously varying. Therefore, Service Level Agreements would be needed to guarantee the service's prices and the offered Quality of Services which are always dependable and interrelated to guarantee revenues maximization for cloud providers as well as improve customers' satisfaction level. Cloud consumers are always searching for a cloud provider who provides good service with the least price, so Cloud provider should use advanced technologies and frameworks to increase QoS, and decrease cost. This paper provides a survey on cloud pricing models and analyzes the recent and relevant research in this field.
\end{abstract}

Keywords: Cloud Computing; Software-as-a-Service (SaaS); Service Level Agreement (SLA); Dynamic pricing; Quality of Service (QoS); revenue maximization; CSL.

\section{INTRODUCTION}

Cloud computing is an emerging parallel and distributed computing paradigm that depends on the internet to deploy computer resources and services dynamically and enables a provider to deploy a single application to execute in multiple machines based on a contract between the cloud providers and the consumers called Service Level Agreement (SLA). Traditionally, the resource/service price is defined in SLA and remains static. This static pricing mechanism has several problems such as overprovisioning as well as under provisioning problems. On the other hand, dynamic pricing is needed to overcome these problems. The central objectives of cloud provider are profit maximization and increase customer satisfaction level (CSL) i.e. the market sharing maximization. To achieve these objectives, the cloud provider need to reduce cost, SLA violations, response time, and power consumption; and deploy services in different prices (Dynamic pricing) based on the current consumer's requirements as well as the level of the offered QoS. On the contrary, the main objectives of cloud consumers are minimizing cost (price) and access services with high quality of services (QoS). To achieve all of these objectives - provider's and consumer's objectives -, the negotiation between them would be established through service level agreement (SLA).

"Service Level Agreement (SLA) is an agreement used to guarantee web service delivery, it defines the understanding and expectations from a service provider and service consumer" [1]. SLA is a legal contract that grantees Quality of Service (QoS) between the cloud provider and the consumers. This contract includes and defines many things, such as parties, services, prices, service level objectives (SLOs), obligations, penalties.

The business organization uses SLA to enlarge market sharing because, through SLA, the provider can increase CSL; as a result improve its profits. When SLA is violated, the CSL go down and some penalties would be enforced.

\subsection{Background}

The Cloud model is cost-effective i.e. the price is reasonable because cloud consumers only pay for their actual usage, they do not need to pay any upfront costs. Also, it is elastic as the cloud provider can deliver more or less according to the customers' needs.

Cloud provider offers different services to cloud consumers [14] at different prices, therefore, two stakeholders - cloud provider and cloud consumer - would be communicated and negotiated about several things such as QoS, price, etc. All of the negotiation points would be written in SLA clearly. Pricing represents an important indicator for success business companies which provide services or products [15]. Cloud provider uses several pricing models to specify the price. This pricing model would be established properly to define the fair price for both stakeholders (providers and consumers). A good pricing model supports cloud providers to achieve their objectives such as profit maximization; meanwhile it considers the cloud consumers.

\subsection{Cloud Computing}

\subsubsection{Cloud Computing Definitions}

Definition 1: "Cloud computing is a model for enabling convenient, on-demand network access to a shared pool of configurable computing resources (for example, networks, servers, storage, applications, and services) that can be rapidly provisioned and released with minimal management effort or service-provider interaction." [17].

Definition 2: "A Cloud is a type of parallel and distributed system consisting of a collection of inter-connected and virtualized computers that are dynamically provisioned and presented as one or more unified computing resource(s) based on service-level agreements established through negotiation between the service provider and consumer." [4].

Definition 3: "Cloud computing is a large-scale distributed computing paradigm that is driven by economies of scale, in which a pool of abstracted, virtualized, dynamically-scalable, managed computing power, storage, platforms, and services 
are delivered on demand to external customers over the Internet." [3]

\subsubsection{Cloud Computing Deployment Models}

Cloud Computing approach is designed mainly to achieve many services generally and services deployment particularly. To deploy services, Cloud computing has several deployment models, such as public, private, community, and hybrid cloud. The brief descriptions for these models as follows:

- Public Cloud: through this model, services could be provisioned for general consumers, and cloud provider responsible for several thing main of them is infrastructure.

- Private Cloud: it is a model by which services could be deployed for particular consumers in an organization, the needed infrastructure owned and managed by the organization or by other third party organization.

- Community Cloud: at this model, cloud provider deploys services to organizations that have common objectives and policies, the needed infrastructure could be managed by one of these organizations or by the third party.

- Hybrid Cloud: Sometimes environment requiring a combination of two or more mentioned deployment models, at this case service provisioned by other model called a hybrid cloud.

\subsubsection{Cloud Computing Service Models}

Cloud computing providers offer their services for cloud consumers through using three fundamental models [5], software-as-a-service (SaaS), platform-as-a-service (PaaS), and infrastructure-as-a-service (IaaS).

- SaaS model: at this model, consumers use the internet to access services (applications) which could be hosted in service provider's company. There would be two cornerstones, the provider, and the consumer. Service provider controls everything whereas service consumer controls application settings only. The common examples of SaaS are Facebook and Twitter. [5]

- PaaS model: through this model, providers deploy several things such as tools, programming environments, and configuration management for consumers to support them to deploy and develop the application. PaaS consumer's examples are software designers, testers, administrators, and developers. Common example of PaaS is Google AppEngine [8].

- IaaS model: this model enables providers to deploy virtual machines (VMs); storage places ...etc for service consumers to help them to build systems. Some example of IaaS consumers are system administrators and system developers. Common example of IaaS is Amazon EC2 [6].

\subsection{Objective}

The objective of this paper is to survey current research on cloud computing pricing models, and analyze and compare their characteristics. We focus on SaaS services. We compare static and dynamic models, and identify the weaknesses of existing models.

\subsection{Organization}

The rest of the paper organized as follows: in the next section the researcher introduces Cloud Computing pricing models, its important concepts, classification, and provides some examples. In section three the paper focuses on the related works to cloud pricing, discusses some of the existing works and draws a comparison among the common existing pricing models. In the last section, the paper gives relevant conclusion and offers some suggestions.

\section{CLOUD COMPUTING PRICING MODELS:}

Demands and revenues are controlled by several factors. And "pricing" is considered to be the most important one. Cloud providers always use pricing to know (1) how much service provisioning could be done for different consumers (2) the relationship between pricing and other issues such as provisioning period and grant discounts.

\subsection{Cloud Computing Pricing Model classification:}

As mentioned in [7, 21], the two common types of pricing models are:

- Fixed Pricing Model: Here the price charging doesn't change, and the cloud provider is someone who determines the price to the resource type in advance. For example, Amazon provides disk space for $\$ 0.15 / \mathrm{GB}$, and service consumers have the same services at all time, such as Payper-use model. According to Yeoa et al. [2], fixed pricing model is more straightforward and easy to understand, but it is unfair for all customers because they are not having the same needs.

- Dynamic Pricing Model: In this model the price charging changes dynamically according to market status quo. The service price could be calculated for each request according to the pricing mechanism that is used. In this case, service consumer requests and receives several types and levels of services in need, such as Market-dependant pricing model.

Table1 bellow shows the strength and weakness of the above types of pricing models:

Table1. Fixed pricing vs. dynamic pricing

\begin{tabular}{|c|c|c|}
\hline $\begin{array}{l}\text { Pricing } \\
\text { Model }\end{array}$ & Advantages & Disadvantages \\
\hline $\begin{array}{c}\text { Fixed } \\
\text { pricing } \\
\text { model }\end{array}$ & $\begin{array}{ll}\text { - } & \text { It supports } \\
\text { assurances for } \\
\text { consumers. } \\
\text { - } \text { Consumers } \\
\text { know how } \\
\text { much they will } \\
\text { pay. } \\
\text { - More } \\
\text { consistent. } \\
\text { - It reduces } \\
\text { risks. } \\
\text { Make profit } \\
\text { estimation } \\
\text { easy. }\end{array}$ & $\begin{array}{l}\text { - Unfair for } \\
\text { consumer: If the } \\
\text { user doesn't } \\
\text { consume the } \\
\text { resource } \\
\text { extensively, he/she } \\
\text { may pay more than } \\
\text { his/her real } \\
\text { utilization. } \\
\text { - It does not allow } \\
\text { provider to change } \\
\text { price at any } \\
\text { account. } \\
\text { Unfair for provider: } \\
\text { During proper } \\
\text { resource utilization } \\
\text { consumer may pay } \\
\text { less than his/her real } \\
\text { utilization. }\end{array}$ \\
\hline $\begin{array}{c}\text { Dynamic } \\
\text { pricing } \\
\text { model }\end{array}$ & $\begin{array}{l}\text { It supports } \\
\text { provider to } \\
\text { maximize } \\
\text { profits with } \\
\text { each } \\
\text { consumer. }\end{array}$ & $\begin{array}{l}\text { - Some consumers } \\
\text { are not interested in } \\
\text { this model as they } \\
\text { prefer a fixed price } \\
\text { to dynamic price. } \\
\text { - Consumers who pay } \\
\text { more feel inequality }\end{array}$ \\
\hline
\end{tabular}




\begin{tabular}{|l|l|l|}
\hline & $\begin{array}{l}\text { Fair for } \\
\text { consumer as it } \\
\text { enables him to } \\
\text { pay according } \\
\text { to the offered } \\
\text { QoS. } \\
\text { - It supports } \\
\text { provider to set } \\
\text { price based on } \\
\text { current state of } \\
\text { the market } \\
\text { (season or } \\
\text { supply and } \\
\text { demand) }\end{array}$ & $\begin{array}{l}\text { consequently having } \\
\text { negative opinions. } \\
\text { In some } \\
\text { environments such } \\
\text { as entertainment } \\
\text { sites consumers do } \\
\text { not prefer dynamic } \\
\text { pricing. }\end{array}$ \\
\hline
\end{tabular}

Financially, the economic efficiency could be measured by two indicators i) the number of allocated resources for providers, and the total of the achieved consumers' requests. ii) The average of the consumers' welfare. Authors of [20] draw a comparison among the number of the achieved consumers' requests, the number of provider's allocated resources, and the average of consumer's welfare with a fixed pricing.

According to [9], in cloud computing, there are several points that determine the price, as follow:

- The annual costs: it is the fees that cloud provider pays annually to buy the resources.

- The period: it is the leasing period of resources by consumers. In this respect some provider confirms that service price could be decreased if the leasing period is long.

- Quality of Services: it is the quality assurance that the cloud providers use to identify the entity of service. Such as service availability, security, and privacy. Some providers increase service price if the level of QoS for service is high.

- The level of resource: it is the age of resource that the cloud consumer rents. Some providers say that older resources mean lower price.

- Maintenance fees: it is the annual cost to maintain and secure resources. Some rented resources become weak or damaged because of the continuous use. These resources could be maintained.

Consumers can assess the providers depending on the following factors:

- Pricing Scheme: the mechanism in which service price could be determined, such as pay-as-you-go model.

- Service Customizability: the way by which provider customizes his SaaS services to meet service consumer's requirements.

- Leasing period: the period, at which customers can consume services, some examples of this period are subscription, pay-per-use, and perpetual.

- Service QoS: the mechanism by which service requirements could be specified; such as scalability, availability, and security.

\subsection{Examples of Cloud Pricing Models:}

There are several pricing models, as follow:

- Pay-as-you-go Model: in this model, the price could be determined by the cloud provider and remains static. Customer pays a fixed price and reserves resources due to the paid period. On the contrary, the customer may utilize the resource improperly i.e. the consumer gets less benefit.[8]

- Subscription Model: here, the price depends on subscription period. If the consumer utilizes resources extensively, the underprovisioning problem will occur. Also, the overprovisioning problem occurs when the customer is not consuming the resources extensively. [8]

- Pricing algorithm for cloud computing Resources: this is a real-time approach, in which provider can maximize revenues and minimize cost. This approach is just a theoretical, and not yet applied. [12]

- Dynamic resource pricing on federated clouds: it is a fair theoretical approach for both provider and consumers because it is dynamic - the price depends on the level of supply and demand. [10]

- Competition-based pricing model: it is a dynamic approach because the determined price depends on competition. This approach could be implemented easily, but it neglects the customers. [13]

\section{RELATED WORK}

This section discusses several existing works, presents weak points, and finally compares some of the pricing models.

In [9] the authors proposed a novel financial economic model, in which customers can gain a high level of QoS. The authors noted that the optimal price by which service provider can recover the initial cost, which was defined between two boundaries. They use the financial option theory to define the lower boundary and the Moor's law to define the upper boundary. However, it disregards the maintenance costs. In $[6,8,11]$ the authors implemented pay-as-you-go pricing model, by which service provider can determine a fixed price. Here, if there is a high demand, the service provider is not allowed to change the period of (resource reservation) or raise a price. On the other side if the demand is low, the consumer negatively pays more than his/her real usage. In $[6,8,11]$, the authors implemented subscription pricing model, by which the price determined according to a period of subscription. This model is good if the customer consumes the service extensively. However, a consumer may do not consume service properly (pay more than use).

In [12], authors introduced Pricing algorithm for cloud computing resources, that could be used for minimizing cost as well as maximizing profits for the service provider. However, this is a fixed model and not suitable on supply/demand changes.

Dynamic resource pricing on federated clouds was introduced in [10], by which the price could be determined depending on the level of supply and demand. However, this model does not support a good scalability during high demand period.

In [13], authors implemented Competition-based pricing model, by which provider sets the price according to competitors. However, in this model, consumers are not taken into consideration.

Customer-based pricing model in [2] was introduced that; the price could be specified according to the customers' needs (what the consumer ready to pay). However, the consumer does not know what he/she is ready to pay at every time.

Table2 shows a comparison among several cloud pricing models, considering the following criteria: the mechanism to determine the price, whether the model is static or dynamic, and the advantages and disadvantages.

Table2. Comparison of several cloud pricing models 
International Journal of Computer Applications Technology and Research

Volume 5- Issue 3, 126 - 131, 2016, ISSN:- 2319-8656

\begin{tabular}{|c|c|c|c|c|c|c|}
\hline$\#$ & Pricing Model & $\begin{array}{l}\text { Type } \\
\text { (Static/ } \\
\text { Dynamic) }\end{array}$ & $\begin{array}{l}\text { Nature ( } \\
\text { Implemented/ } \\
\text { theoretical ) }\end{array}$ & Mechanism & Advantages & Disadvantages \\
\hline 1 & $\begin{array}{l}\text { Subscription } \\
\text { Model }[8,11]\end{array}$ & Static & Implemented & $\begin{array}{l}\text { Cloud provider defines } \\
\text { Resource/Service prices } \\
\text { depending on lease period }\end{array}$ & $\begin{array}{l}\text { It is good for consumer } \\
\text { when } \\
\text { Resources/Services are } \\
\text { utilized extensively }\end{array}$ & $\begin{array}{l}\text { Consumer may pay } \\
\text { more than the real } \\
\text { utilization cost when } \\
\text { he/she does not use } \\
\text { Resources/Services } \\
\text { properly }\end{array}$ \\
\hline 2 & $\begin{array}{l}\text { Pay-as-you-go } \\
\text { Model }[8,11]\end{array}$ & Static & Implemented & $\begin{array}{l}\text { Cloud provider } \\
\text { determines a constant } \\
\text { Resource/Service price }\end{array}$ & $\begin{array}{l}\text { Resources/Services are } \\
\text { available during } \\
\text { reservation period, and } \\
\text { the price is known }\end{array}$ & $\begin{array}{l}\text { Overprovisioning } \\
\text { and } \\
\text { underprovisioning } \\
\text { problems may occur. } \\
\text { The price is } \\
\text { unchangeable }\end{array}$ \\
\hline 3 & $\begin{array}{l}\text { Pay-for- } \\
\text { resources } \\
\text { model }[8,11]\end{array}$ & Static & Implemented & $\begin{array}{l}\text { Cloud provider } \\
\text { determines } \\
\text { Resource/Service prices } \\
\text { according to the cost. }\end{array}$ & $\begin{array}{l}\text { Maximizes resource } \\
\text { utilization }\end{array}$ & $\begin{array}{l}\text { Difficult to be } \\
\text { implemented }\end{array}$ \\
\hline 4 & $\begin{array}{l}\text { Dynamic } \\
\text { resource } \\
\text { pricing on } \\
\text { federated } \\
\text { clouds [12] }\end{array}$ & Dynamic & Theoretical & $\begin{array}{l}\text { Cloud provider uses } \\
\text { current level of supply/ } \\
\text { demand to determine } \\
\text { Resource/Service prices }\end{array}$ & $\begin{array}{l}\text { Increases consumers' } \\
\text { satisfaction and } \\
\text { maximizes the number } \\
\text { of their profitable } \\
\text { requests }\end{array}$ & $\begin{array}{l}\text { It does not support a } \\
\text { good scalability } \\
\text { during high demand } \\
\text { period }\end{array}$ \\
\hline 5 & $\begin{array}{l}\text { Value-based } \\
\text { pricing [20] }\end{array}$ & Dynamic & Implemented & $\begin{array}{l}\text { Resource/ Service prices } \\
\text { are defined depending on } \\
\text { the customer's point of } \\
\text { view }\end{array}$ & Increases revenues & Hard to implement \\
\hline 6 & $\begin{array}{l}\text { Competition- } \\
\text { based pricing } \\
{[13]}\end{array}$ & Dynamic & Implemented & $\begin{array}{l}\text { Cloud provider uses } \\
\text { competitors' prices to } \\
\text { determine the current } \\
\text { price for service/resource }\end{array}$ & Easy to implement & $\begin{array}{l}\text { Ignores the cloud } \\
\text { customers }\end{array}$ \\
\hline 7 & $\begin{array}{l}\text { Datacenter net } \\
\text { profit } \\
\text { optimization } \\
\text { with } \\
\text { individual job } \\
\text { deadlines [18] }\end{array}$ & Dynamic & Theoretical & $\begin{array}{l}\text { Cloud provider uses job } \\
\text { scheduling mechanisms to } \\
\text { set Resource/ Service } \\
\text { prices }\end{array}$ & $\begin{array}{l}\text { Maximizes cloud } \\
\text { provider's revenues, } \\
\text { minimizes power } \\
\text { consumption cost }\end{array}$ & $\begin{array}{l}\text { It doesn't take in } \\
\text { consideration the } \\
\text { heterogeneous } \\
\text { servers. } \\
\text { Difficult to } \\
\text { implement }\end{array}$ \\
\hline 8 & $\begin{array}{l}\text { Genetic model } \\
\text { for pricing in } \\
\text { cloud } \\
\text { computing } \\
\text { markets [17] }\end{array}$ & Dynamic & Theoretical & $\begin{array}{l}\text { Price is specified by cloud } \\
\text { provider depending on the } \\
\text { state of a real time } \\
\text { market. }\end{array}$ & $\begin{array}{l}\text { Maximizes revenues, } \\
\text { flexible implementation }\end{array}$ & $\begin{array}{l}\text { Very critical during } \\
\text { the (rise and fall) } \\
\text { demand period. }\end{array}$ \\
\hline 9 & $\begin{array}{l}\text { A novel } \\
\text { financial } \\
\text { economic } \\
\text { model [9] }\end{array}$ & Dynamic & Theoretical & $\begin{array}{l}\text { Cloud provider sets } \\
\text { Resource/Service prices } \\
\text { between upper and lower } \\
\text { boundaries }\end{array}$ & $\begin{array}{l}\text { Maximizes profits for } \\
\text { cloud provider and } \\
\text { improves QoS for cloud } \\
\text { consumer }\end{array}$ & $\begin{array}{l}\text { Maintenance costs } \\
\text { are not taken in } \\
\text { consideration. }\end{array}$ \\
\hline 10 & $\begin{array}{l}\text { Customer- } \\
\text { based pricing } \\
{[13]}\end{array}$ & Dynamic & Implemented & $\begin{array}{l}\text { Cloud consumers define } \\
\text { the current price }\end{array}$ & $\begin{array}{l}\text { Cloud consumer is } \\
\text { taken into consideration }\end{array}$ & Difficult to set price \\
\hline 11 & $\begin{array}{l}\text { Cost-based } \\
\text { pricing [19] }\end{array}$ & Dynamic & Implemented & $\begin{array}{l}\text { Cloud provider specifies } \\
\text { profit level to set } \\
\text { Resource/Service prices }\end{array}$ & $\begin{array}{l}\text { Cloud provider can } \\
\text { define the price easily }\end{array}$ & $\begin{array}{l}\text { It doesn't considers } \\
\text { cloud consumer }\end{array}$ \\
\hline 12 & $\begin{array}{l}\text { Pricing } \\
\text { algorithm for } \\
\text { cloud } \\
\text { computing } \\
\text { Resources } \\
{[10]} \\
\end{array}$ & Dynamic & Theoretical & $\begin{array}{l}\text { Resource/Service prices } \\
\text { are set according to the } \\
\text { current market state. }\end{array}$ & $\begin{array}{l}\text { It is better for cloud } \\
\text { provider because it } \\
\text { maximizes revenues by } \\
\text { reducing cost }\end{array}$ & $\begin{array}{l}\text { Useless when } \\
\text { supply/demand differ } \\
\text { quickly }\end{array}$ \\
\hline
\end{tabular}




\section{CONCLUSION}

In this paper, we surveyed different types of cloud pricing models. We compared static pricing model versus dynamic pricing model. Based on this comparison, we conclude that on one hand the static model is easy for both understand-ability and profit estimation but some problems such as under provisioning and over provisioning may occur. On the other hand the dynamic pricing model is fair for consumers because it supports them to pay depending on the QoS required; also it is fair for the provider so it help him to maximize profits.

Also, during this survey, we presented detailed comparison among twelve pricing models based on the following factors: the type (static/dynamic), nature (theoretical/implemented), the mechanism to determine price, the advantages, and disadvantages. Depending on this comparison we note that all of the static models are implemented but some of the dynamic models are theoretical, on the static models the provider defines the price but on the dynamic models the price could be defined by the provider to maximize revenues and rarely optimized for the consumers.

In summary, due to the fact that cloud computing services have dynamic behavior with pay-as-you-go models, it is necessary to conclude that the dynamic pricing models are much more adequate for the consumers because they adapt to different variable needs. Also, they are batter for the providers because they need to support Multi-Tenants and change (increase/decrease) in the price depending on the market state. Finally, we noted that most of pricing models favor the providers over the consumers. Our research suggests that there is a need for new pricing models that take the two stakeholders, the provider and the consumer, in its consideration.

\section{REFERENCES}

[1] Jin, L. J., and Machiraju, V. A. Analysis on Service Level Agreement of Web Services, (June 2002).

[2] C. S. Yeoa, S. Venugopalb, X. Chua and R. Buyyaa, "Autonomic Metered Pricing for a Utility Computing Service", Future Generation Computer Syst., vol. 26, no. 8, (2010).

[3] Foster I, Yong Z, Raicu I, Lu S Cloud computing and grid computing 360-degree compared. In: Proc 2008 grid computing environments workshop, pp 1-10, (2008).

[4] Buyya, R., and Alexida. D. A Case for Economy Grid Architecture for Service Oriented Grid Computing. In Proceedings of the 10th International Heterogeneous Computing Workshop (HCW), San Francisco, CA, (2001).

[5] W. Voorsluys, J. Broberg, and R. Buyya, Introduction to Cloud Computing," Cloud Computing: Principles and Paradigms, chapter 1, pp. 1-41.Technical Report HPL2002-180, Software Technology Laboratories, HP Laboratories, (2011).

[6] Varia, J. Architecting Applications for the Amazon Cloud. Cloud Computing: Principles and Paradigms, Buyya, R., Broberg, J., Goscinski, A. (eds), ISBN-13: 9780470887998, Wiley Press, New York, USA. Web http://aws.amazon.com. (2010).

[7] A. Osterwalder, "The Business Model Ontology - A Proposition in a Design Science Approach", Doctoral thesis, University of Lausanne, (2004).

[8] Google App Engine, https://appengine.google.com/.(2015)

[9] B. Sharma, R. K. Thulasiram, P. Thulasiraman, S. K. Garg and R. Buyya, "Pricing Cloud Compute Commodities: A Novel Financial Economic Model", Proc. of IEEE/ACM Int. Symp. on Cluster, Cloud and Grid Computing, (2012).

[10] M. Mihailescu and Y. M. Teo, "Dynamic Resource Pricing on Federated Clouds", Proc. 10th IEEE/ACM Int. Symp. on Cluster. Cloud and Grid Computing, (2010).
[11] Windows Azure, http://www.windowsazure.com/en-us/.

[12] H. Li, J. Liu and G. Tang, "A Pricing Algorithm for Cloud Computing Resources”, Proc. Int. Conference on Network Computing and Inform. Security, (2011).

[13] J. Rohitratana and J. Altmann, "Agent-Based Simulations of the Software Market under Different Pricing Schemes for Software-as-a-Service and Perpetual Software", Economics of Grids, Clouds, Systems, and Services, ser. Lecture Notes in Computer Science, Altmann et al., Eds. Springer Berlin/Heidelberg, pp. 6296. (2010).

[14] A. Monaco, "A View inside the Cloud", http://theinstitute.ieee.org/technology-focus/technologytopic/a-view-inside-the-cloud.

[15] S. Dutta, M. Zbaracki and M. Bergen, "Pricing Process as a Capability: A Resource-Based Perspective", Strategic Management Journal, vol. 27, no. 7, (2003).

[16] M. Macias and J. Guitart, "A Genetic Model for Pricing in Cloud Computing Markets", Proc. 26th Symp. of Applied Computing, (2011).

[17] W. Wang, P. Zhang, T. Lan and V. Aggarwal, "Datacenter Net Profit Optimization with Individual Job Deadlines", Proc. Conference on Inform. Sciences and Systems, (2012).

[18] S. Lehmann and P. Buxmann, "Pricing Strategies of Software Vendors", Business and Information Systems Engineering, (2009).

[19] P. Nähring, "Value-Based Pricing", Bachelor Thesis, Linnaeus University, (2011).

[20] M. Mihailescu and Y. M. Teo, "On economic and computational-efficient resource pricing in large distributed systems," in Cluster, Cloud and Grid Computing (CCGrid), 2010 10th IEEE/ACM International Conference on, may 2010 , pp. $838-843$.

[21] Samimi, P.; Patel, A.; , "Review of pricing models for grid \& cloud computing," Computers \& Informatics (ISCI), 2011 IEEE Symposium on , vol., no., pp.634-639, 20-23 (March 2011).

\section{AUTHRORS BIOGRAPHIES}

Taj Eldin Suliman M. Ali: B.Sc. in Computer science at Sudan University (SUST), and M.Sc.in Computer science at Khartoum University. From 2009 to 2015 he was work as a lecturer and academic coordinator, College of Computer Studies at National Ribat University, now he is a lecturer. From 2010 to 2015 he was work as a lecturer and academic coordinator, College of Computing and Health informatics at National University - SUDAN, now he is a lecturer. During 2006 to 2008 he was work as a lecturer at Bayan Collage, 2008 to 2009 he was work as Dean of IT department at Bayan Collage. From 2002 to 2005 he was work as TA at Bayan Collage and also works as a programmer. Currently, he is a Ph.D. student at Sudan University of Science and Technology, College of Computer Science and Information Technology (SUST), my research interests in Pricing models and Cloud Computing.

Hany H. Ammar BSEE, BS Physics, MSEE and Ph.D. EE, is a Professor of Computer Engineering in the Lane Computer Science and Electrical Engineering department at West Virginia University. He has published over 170 articles in prestigious international journals and conference proceedings. He is currently the Editor in Chief of the Communications of the Arab Computer Society OnLine Magazine. He is serving and has served as the Lead Principal Investigator in the projects funded by the Qatar National Research Fund under the National Priorities Research Program. In 2010, he was awarded a Fulbright Specialist Scholar Award in Information Technology funded by the US State Department - Bureau of 
International Journal of Computer Applications Technology and Research

Volume 5- Issue 3, 126 - 131, 2016, ISSN:- 2319-8656

Education and Cultural Affairs. He has been the Principal Investigator on a number of research projects on Software Risk Assessment and Software Architecture Metrics funded by NASA and NSF, and projects on Automated Identification Systems funded by NIJ and NSF. He has been teaching in the areas of Software Engineering and Computer Architecture since 1987.In 2004, he coauthored a book entitled Pattern-Oriented Analysis and Design: Composing Patterns to Design Software Systems, AddisonWesley. In 2006, he co-authored a book entitled Software Engineering: Technical, Organizational and Economic Aspects, an Arabic Textbook. 